\title{
Optimization of Production Logistics
}

\author{
Rudolf Kampf', Martina Hlatká' ${ }^{*}$, Ladislav Bartuška' \\ 1 Vysoká Škola Technická a Ekonomická v Českých Budějovicích, Okružní 517/10, 37001 České \\ Budějovice, Czech Republic \\ * Corresponding author's e-mail: hlatka@mail.vstecb.cz
}

\begin{abstract}
The paper focuses on the optimization of production logistics within the selected company, which is going to relocate the machining centre to the Czech Republic. The aim of this paper was to design a suitable conveyor to optimize the machining centre's entire production process. On the basis of the company's input requirements, the necessary calculations were carried out, which led to the construction of the conveyor model. Proposing the model was preceded by selecting a suitable conveyor which will be used in production.
\end{abstract}

Keywords: production logistics, production optimization, conveyor.

\section{INTRODUCTION}

The development of economy in all countries brings increased demands on companies. These are especially the issues of industrial logistics, personnel logistics, and green logistics,. In order to stay competitive, companies strive for providing high quality services, but also for reducing costs. Production logistics management is very important for the whole logistics process. The decisions taken in this part of the logistics process have a direct impact on the level of customer services provided, the ability of the company to compete with other companies, and on the level of sales and profit the company is able to make.

Optimization of logistics processes is a topical issue, as it influences the resulting price for the customer as well as the level of customer service. This paper is focused on the possibility of improving the logistics processes in a chosen company. It is the optimization of the production process in a selected company using designing a suitable conveyor transporter that would correspond to the conditions in that company $[1,2,18]$.

\section{METHODOLOGY}

For the purposes of this study, a company involved especially in foundry, machining, assembling and additional processes (e.g. manufacturing of moulds, quenching with a modified atmosphere, galvanic zinc coating, etc.) was considered. The company's production portfolio includes the production of filtration and hydraulic systems parts, handling equipment, machine tools, castings from zinc and aluminium alloys, low-pressure castings from aluminium and cast iron castings. The main customers are global and multinational automotive industry corporations. Since there is a steady increase in production, it is necessary to adapt the production organization to this trend. Another reason for optimization is the movement of the machining centre from Germany to the Czech Republic. The second requirement involves achieving leaner production in order to reduce the space. However, these requirements must be consistent with the effort for improving the customer service and the productivity of work. The whole production process consists of interdependent activities, and any unevenness or failure of a production process part will cause se- 


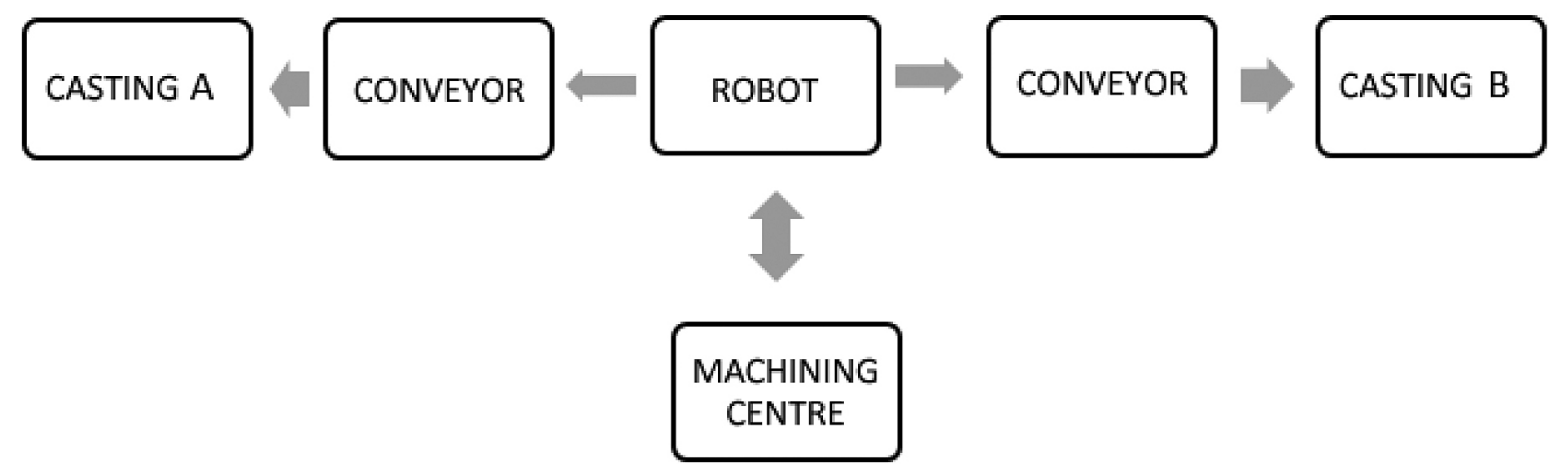

Fig. 1. Scheme of manufacturing process

rious problems in production. For this reason, an effective design of a production hall is necessary. The optimization will be focused on the machining centre. A new conveyor will be designed for this hall and it will be a part of the production line. The conveyor must conform to the requirements and layout of the hall. In the production hall, two types of castings will be machined. Figure 1 shows a simplified design of the production line $[3,16]$.

The requirement imposed to the machining centre is to process two castings in two minutes. After machining, the machine plates in the centre rotate. The robot with its arm, which is capable of removing two castings at the same time, moves the castings from the machine plate of the machining tool to the conveyor. The radius of the robot arm is $1.5 \mathrm{~m}$. Therefore, the rotary plates of the machining centre, part of the input conveyor and part of output conveyor must be at the robot's arm reach. At the point of the input conveyor, the robot must be capable of reaching four castings. At the point of the output conveyor, it must reach at least two castings. Then the whole process is repeated.

\section{CASE STUDY}

As already indicated above, the machining centre must be capable of processing two castings per minute. Then the machine plates rotate. Another aspect important for designing a suitable conveyor is the casting dimension. The distance between the conveyors is $550 \mathrm{~mm}$. In the safety zone (behind the fencing), four castings of the given type must always have to be prepared. The zone for machine operators is set to $1,500 \mathrm{~mm}$. The height of the conveyor must be between 460 and $700 \mathrm{~mm}$ above the ground. Given the size of the production hall, the conveyor must be as narrow as possible, while the length must be about 2,000 to $3,500 \mathrm{~mm}$. On the basis of these input values, the width of the conveyor is determined.

Suitable conveyor types for transporting castings include flat belt conveyor, belt conveyor, and chain conveyor. After consultation with the management of the company, chain conveyor was chosen for its space requirements compared to belt conveyor and high resistance to the external environment. Chain conveyors consist of the following parts: drive pulley, return idlers, supporting structure with a guide rail and articulated belt with tension assembly. The layout of the workplace is very important for the design. On its basis, several basic dimensions of the conveyor will be calculated. In the paper, only some of the calculations, based on which the conveyor is designed, are mentioned $[4,5,12,16]$.

The conveyor dimensions are partly given by the company. The height of the conveyor must be between 460 and $700 \mathrm{~mm}$ above the ground; it will thus be determined at $600 \mathrm{~mm}$. The width of the conveyor is not given, but it is necessary to design a conveyor that would be as narrow as possible, taking into account the operating capacity of the machine and layout of the production hall. The width of the conveyor is three times the average casting width, because it is necessary to take the space for the frame and sprocket wheels into account $(170+165 / 2=167.5 \mathrm{~mm})$.

The design of the conveyor length and the location of the conveyor relative to the zero point selected on the machine plates of the machining centre are influenced by the requirements of the company, workplace layout and the minimum distance the machine operators must access. The company has determined the length of the conveyor between 2,500 and $3,000 \mathrm{~mm}$. The centre 
of the front input conveyor surface from its front on the machine centre in the $\mathrm{x}$-axis can be within a range from the minimum distance where the conveyor does not interfere with the robot stand, which corresponds to $720 \mathrm{~mm}$, and the maximum distance (1910), which is defined by fencing. The company's requirement is that the robot must be able to reach 4 castings in the safety zone. Therefore, the conveyor in the $\mathrm{x}$-axis can be moved only by $290 \mathrm{~mm}(1910-720=1190-900=290$ $\mathrm{mm})$. The value of $900 \mathrm{~mm}$ is the size of four castings placed side by side with a gap between them, increased by the size from the edge from which castings cannot be removed $[6,7,14,17]$.

The position of the conveyor was determined based on calculations. The distance was determined as the distance in the $\mathrm{x}$-axis $\mathrm{x} 720 \mathrm{~mm}$ from the front end. The distance of the coordinate in the y-axis was determined by summing the width of the output conveyor, its distance from the front end, the distance between the conveyors, which is determined by the company's requirement, and a half of the width of the input conveyor $(550+200+550+250=1550 \mathrm{~mm})$.

At this point, the whole length of the conveyor was determined. The overall length includes the safety distance (fenced zone) and unfenced zone for machine operators. In the fenced zone, the distance is $1,190 \mathrm{~mm}$ and the zone for machine operators is 1,500 , which is $2,690 \mathrm{~mm}$ in total (rounded off to $3,000 \mathrm{~mm}$ ).

\section{Calculation of amount of material transported}

The transport speed was determined as $0.1 \mathrm{~m} / \mathrm{s}$.

$$
\begin{gathered}
Q_{m}=3600 \times \frac{m}{t_{K}} \times v\left[\mathrm{Kgh}^{-1}\right] \quad \text { (1) } \begin{array}{l}
\text { force Fn acting in the oppositaional force Fg. The } \mathrm{p} \\
\text { gravitan chain be calculated a } \\
\text { one can }
\end{array} \\
\mathrm{P}_{\mathrm{r}}=\frac{\mathrm{m} \times \mathrm{g} \times \mathrm{f} \times \mathrm{v}_{\mathrm{K}}+\frac{1}{2} \mathrm{~m} \times \mathrm{a}_{\mathrm{P}} \times \mathrm{v}_{\mathrm{P}}}{2} \\
P_{r}=\frac{69.5 \times 9.81 \times 0.15 \times 0.1+\frac{1}{2} 69.5 \times 0.5 \times 0.1}{2}=5.982 \mathrm{~W}
\end{gathered}
$$

$Q_{m}=3600 \times \frac{1,2}{0,1905} \times 0,1 \doteq 2268\left[\mathrm{Kgh}^{-1}\right](2)$

The calculation of the amount of the material transported can also be expressed as a number of pieces per hour as follows:

$$
Q_{K}=\frac{Q_{m}}{m}=3600 \times \frac{v}{t_{K}}\left[h^{-1}\right]
$$

$$
Q_{K}=\frac{2268}{1,2}=3600 \times \frac{0,1}{0,1905} \doteq 1890 k s\left[h^{-1}\right](4)
$$

The calculations above indicate the amount of the material transported in continuous operation $[8,11,13]$.

\section{Engine with gearbox}

On the basis of the agreement with the SEWUSOCOME company, an engine with a transmission will be used. It is a worm gearbox with engine power of $0.12 \mathrm{KW}$. The weight of the engine with gearbox is $22 \mathrm{~kg}$. Due to its dimensions $(345 \times 178$ $\times 141.5 \mathrm{~mm}$ ) it would be too large; therefore, chain transmission was used in order to meet the requirement for the smallest conveyor width possible.

\section{Calculation of the chain}

For the main part of the conveyor, the 10B1 chain was chosen. Firstly, the forces acting on chain were determined. The pallet mounted on the plate moves in the direction of the force $\mathrm{F}$ and produces the friction force acting in the opposite direction. Inertia force Fs acts on the DESKA with the pallet in the same direction as the friction force. The last forces acting are the normal force Fn acting in the opposite direction than the gravitational force $\mathrm{Fg}$. The power transmitted by one chain can be calculated as follows:

\section{Transmission spindle}

Before calculating the forces acting on the spindle, it is necessary to calculate the torque. The calculation was based on output revolutions and engine power values. The torque is $1041174 \mathrm{Nm}$.

Formula for calculating the force acting on the spindle: 


$$
F=\frac{2 \times M_{K}}{D}
$$

Calculation of the force acting below the sprocket wheel with 21 cogs:

$$
\begin{gathered}
F_{1}=\frac{2 \times M_{K}}{D_{1}}\left[N=\frac{N m m}{\mathrm{~mm}}\right] \\
F_{1}=\frac{2 \times 104174}{106.51}=1959.14 \mathrm{~N}
\end{gathered}
$$

Calculation of force acting below the sprocket wheels with 34 cogs.

$$
\begin{gathered}
F_{2}=\frac{2 \times M_{K}}{D_{2}} \\
F_{2}=\frac{2 \times 104174}{172.05}=1210.97 \mathrm{~N}
\end{gathered}
$$

Figure 2 shows the calculation of balance forces and reactions:

$$
\begin{gathered}
R_{B}=\frac{F_{2} \times(b+c)-F_{1} \times a}{d} \\
R_{B}=\frac{1210.97 \times(72.55+146.65)-1959.14 \times 41.4}{205,2}=898.32 \mathrm{~N} \\
\boldsymbol{R}_{A}=F_{1}+2 \times F_{2}-\frac{F_{2} \times(b+c)-F_{1} \times a}{d} \\
\mathrm{R}_{\mathrm{A}}=1959.14+2 \times 1210.97-\frac{1210.97 \times(72.55+146.65)-1959.14 \times 41.4}{205.2}=3482.76 \mathrm{~N}
\end{gathered}
$$

On the basis of the equations, the reactions in the bearings A and B were identified.

Subsequently, the bending moment was calculated. The maximum bending moment was identified at $72.55 \mathrm{~mm}$ based on the calculation,. For combined stress, reduced stress is given, which is defined as the sum of the torsion and bending stress vectors. The sub-calculations are not showed in the paper. Next, we use the reduced bending moment in the equation for calculation of the stress and express the diam- eter $d$ in the critical point to obtain the value $d \geq 23$ $\mathrm{mm}$. The diameter of the transmission spindle must be greater than $23 \mathrm{~mm}$. The spindle deflection of the $\mathrm{y}=0.0645 \mathrm{~mm}$ beyond the maximum allowed limit. The results indicate that the spindle must be adjusted.

\section{Drive spindle}

On the basis of the calculations, it was determined that the diameter of the drive spindle is 25

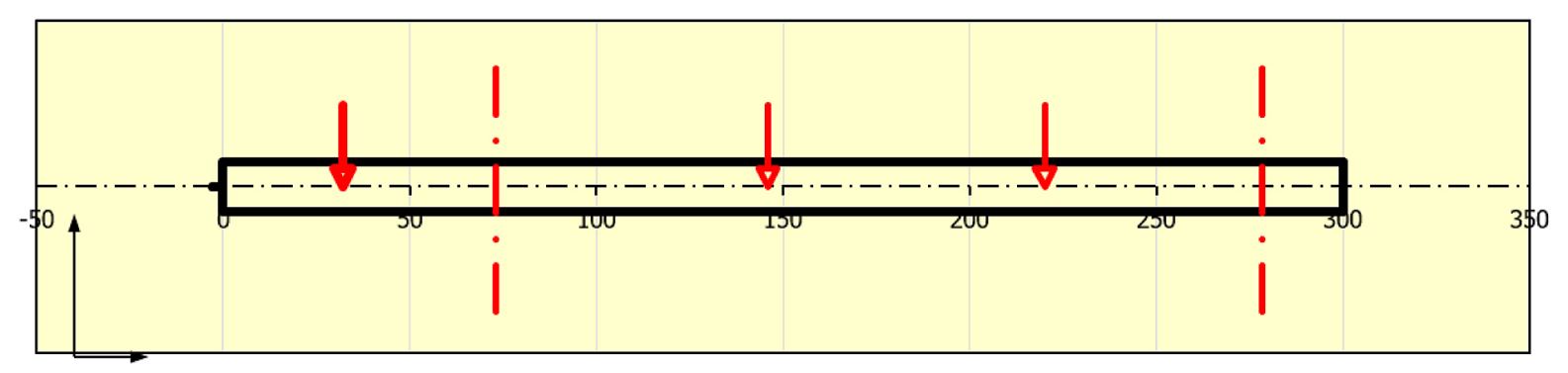

Fig. 2. Forces acting on transmission spindle 
$\mathrm{mm}$, which means that the drive shift corresponds with the calculation. Figure 3 shows the deflection of the spindle with the diameter of $25 \mathrm{~mm}$.

\section{Parts transmitting the torque}

For transmitting the torque from the transmission spindle to the sprocket wheels, tight splines were used. Tight splines were chosen in accordance with the ČSN 022562 standard - Tight spline b x h $\mathrm{x} 1$ (spline breadth $\mathrm{x}$ spline height $\mathrm{x}$ spline length).

The breadth and height of the spline are given by the diameter of the spindle. For the $30 \mathrm{~mm}$ diameter, the corresponding breadth is $8 \mathrm{~mm}$, while the corresponding height is $7 \mathrm{~mm}$. The length of the spline can range between 20 and $90 \mathrm{~mm}$. In this case, spline with the dimensions of $8 \times 7 \times 28$, which corresponds to the technical standard, will be chosen. The calculation of the spline consists of the punching and shear check.

\section{RESULTS}

It followed from the calculations for the transmission spindle that the smallest acceptable diameter of the spindle is $23 \mathrm{~mm}$. A spindle of such a diameter would not withstand the strain anticipated. Therefore, the diameter has been increased to $30 \mathrm{~mm}$. The deflection, due to which the spindle was not suitable, has changed from $\mathrm{y}=0.0645 \mathrm{~mm}$ to $\mathrm{y}=0.019 \mathrm{~mm}$. New deflection is shown in Figure 4.

Given the size of the spindle, the diameter of the sprocket wheels was set to $30 \mathrm{~mm}$. The bearings where the transmission spindle is mounted are set up to FLCTE 30. The dimensions of the bearings are $\mathrm{U}-38.1 \mathrm{~mm}$ and $\mathrm{H} 112.5 \mathrm{~mm}$. On the basis of the individual calculations, a chain conveyor

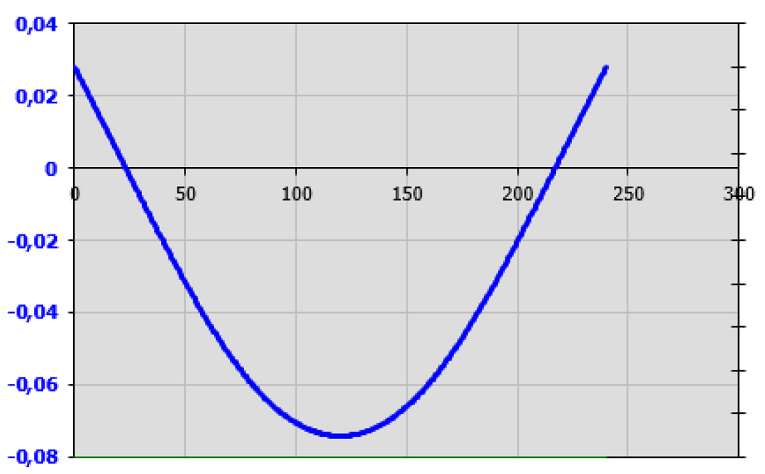

Fig. 3. Deflection of drive spindle [mm]

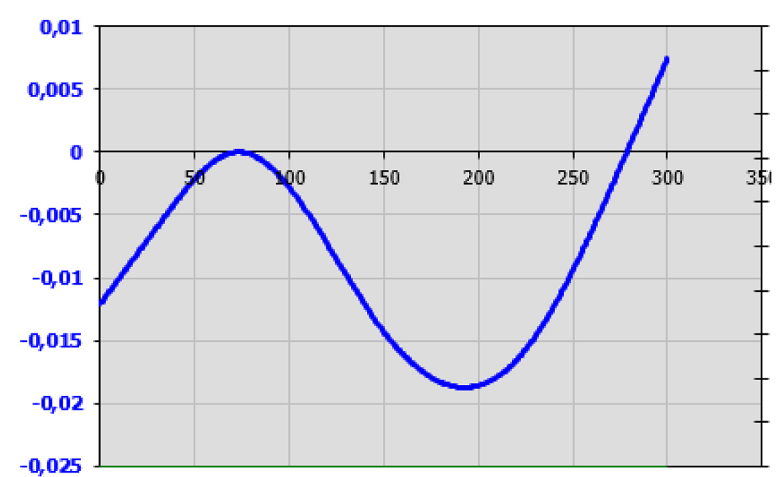

Fig. 4. Deflection of transmission spindle after changing the diameter $[\mathrm{mm}]$

model was designed. Its most important parts include engine with a transmission. The engine is attached to the engine plate, which is fastened to the frame using screws. On the transmission, a spindle with a sprocket wheel with 21 cogs, which is a part of the secondary transmission system, is located. The transmission of the torque is ensured using tight spline. Through the chain, the torque is further transmitted over the tension pulley, which is also attached to the engine plate and the sprocket wheel (with $21 \mathrm{cogs}$ ) on the transmission spindle. In order to protect the operators from injury, the entire secondary transmission system is covered. The transmission spindle is mounted in the bearings with a casing, which are attached to the frame. On the spindle, there are two sprocket wheels with 34 cogs propelling the chains with the drivers. The sprockets are secured against axial movement along the spindle by means of locking rings. The transmission of the torque is ensured using the tight splines. The chains circulate between the sprockets on the transmission spindle and the drive spindle. The drive spindle is mounted in flanged bearings. The body of the bearings is secured

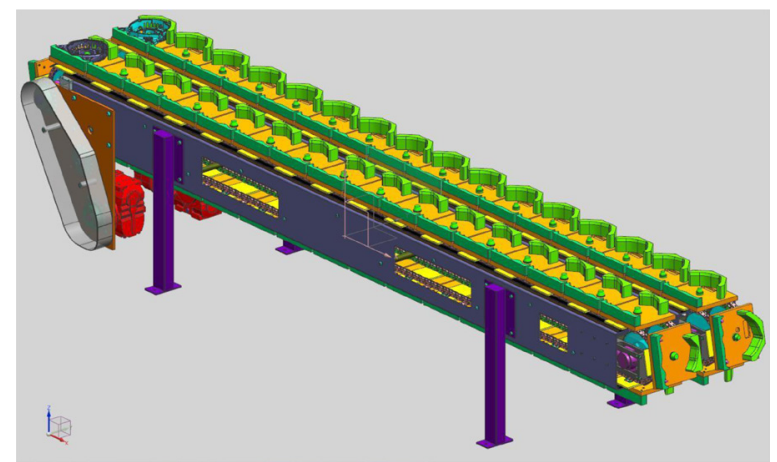

Fig. 5. Final version of the conveyor (3D model) 
against axial movement by insertion in the bearings holder, which is bolted to the frame. Locking rings and set screw prevent axial displacement and overspinning of the sprockets. The final design of the conveyor is shown in Figure $5[9,10,12]$.

\section{CONCLUSION}

The objective of this paper was to show the optimization of the production process in a selected company. The company plans to move the machining centre from Germany to the Czech Republic. On the basis of the requirements of the chosen company, a production line was to be designed, with the aim to optimize the whole process. After consultation with the chosen company, a suitable conveyor for castings was to be designed. For a functional design of a chain conveyor, it was necessary to create a process that would ensure a sound solution. The process or algorithm of consecutive steps should consist of instructions, design, design control, and modification, according to the results of the control and final solution. The instructions should be as precise as possible, and should contain all important parameters. Creating the design involves calculations and their application. After the control part of the algorithm, the design is modified and subsequently, there is a result in the form of a functional design. At this point, the transmission spindle was corrected. If the correction did not happen, the functionality would not be ensured. For the whole casting production process, chain conveyor was chosen as the most suitable one.

\section{REFERENCES}

1. Polák J., Pavliska J. and Slíva A. Dopravní a manipulační zařízení. Ostrava: Vysoká škola báňská - technická univerzita, 2001, ISBN 80-248-0043-8.

2. ČSN 26 0002. Manipulace s materiálem. Názvosloví. Praha: Úřad pro technickou normalizaci, metrologii a státní zkušebnictví, 1983.

3. Polák J. Dopravní a manipulační zařízení. Ostrava: VŠB - technická univerzita, 2003, ISBN 80-2480493-X.

4. Blatnický M., Dižo J. and Blatnická M. Structural design of soldering station chain conveyor working positions. MATEC web of conferences 157, 2018.

5. Si Wei J., Gang Y.J. and Qi Feng. Development of a chain - driven travelling robot. IOP conference series: materials science and engineering, 2018, vol 392(6).
6. ČSN 02 2562. Pera těsná s mezními úchylkami šírky e7 nebo h9. Praha: Úřad pro technickou normalizaci, metrologii a státní zkušebnictví, 2003.

7. ČSN 02 3311. Kloubové řetězy, Válečkové řetězy, Rozměry. Praha: Úřad pro technickou normalizaci, metrologii a státní zkušebnictví, 1973.

8. Leinveber J. and Vávra P. Strojnické tabulky: pomocná učebnice pro školy technického zaměření. Úvaly: Albra, 2005, ISBN 80-7361-011-6.

9. McGuire P.M. Conveyors: Application, Selection, and Integration. CRC Press, 2014, ISBN 978-1-4398-0390-5.

10. Wang X., Li B., Wang S., Yang Z. and Cai L. The transporting efficiency and mechanical behavior analysis of scraper conveyor. Proceedings of the institution of mechanical engineers, Part C: Journal of mechanical engineering science 232(18), 2018, 3315-3324.

11. Lonkwic P., Rozylo P. and Debski H. Numerical and experimental analysis of the progressive gear body with the use of finite-element method. Eksploatacja i Niezawodnosc - Maintenance and Reliability 17(4), 2015, 544-550.

12. Fedorko G., Husakova N. and Dudáš G. Design of allocation of new technological equipment within the frame of production process in company Getrag Ford Transmissions. Acta Montanistica Slovaca $15,2010,14-22$.

13. Neradilová H. and Fedorko G. The Use of Computer Simulation Methods to Reach Data for Economic Analysis of Automated Logistic Systems. Open Engineering 6(1), 2016, 700-710.

14. Mantič M., Kul'ka J., Krajňák J., Kopas M. and Schneider M. Influence of selected digitization methods on final accuracy of 3D model. Production Management and Engineering Sciences 2016, 475-480.

15. Debski H., Teter A., Kubiak T. and Samborski S. Local buckling, post-buckling and collapse of thin-walled channel section composite columns subjected to quasi-static compression. Composite structures 136, 2016, 593-601.

16. Jachowicz T.; Garbacz T.; Tor-Świątek A. et al.: Investigation of Selected Properties of InjectionMolded Parts Subjected to Natural Aging. INT J POLYM ANAL CH, 20 (4), 2015, 307-315; DOI: 10.1080/1023666X.2015.1016788.

17. Molnár, V., Fedorko, G., Stehlíková, B., Michalik, P., Weiszer, M., A regression model for prediction of pipe conveyor belt contact forces on idler rolls, Meas. J. Int. Meas. Confed. 46 (2013) 3910-3917. doi:10.1016/j.measurement.2013.07.045.

18. Molnár, V., Fedorko, G., Stehlíková, B., Michalik, P., Kopas, M., Mathematical models for indirect measurement of contact forces in hexagonal idler housing of pipe conveyor, Meas. J. Int. Meas. Confed. 47 (2014) 794-803. doi:10.1016/j.measurement.2013.10.012. 